\title{
17. PLANNING WITH PEOPLE
}

\author{
Reflections on Participation and Learning on Deliberative Walks
}

\section{INTRODUCTION}

Literature on democratic deliberation rarely focuses on learning processes as Prosser et al. (2018, p. 213) note, "what is often lacking is detail on the pedagogy of learning". This chapter focuses on the participatory learning that takes place in 'Deliberative Walks', a novel method first proposed by Ehrström and Raisio (2014). I will outline what this involves and the impact Deliberative Walks have, and might have. These reflections builds on previous work in which a colleague and I analyzed two case studies (Raisio \& Ehrström, 2017), exploring the potential of Deliberative Walks alongside findings from a pilot study on an initiative called Studentlab Deliberative Walks. These walks can be regarded as both a form of pedagogy and a type of research. It highlights the importance of place in learning and as Szczepanski (2013) points out, where education takes place is a vital pedagogical question. It also underlines the need for innovation and creativity to develop forms of education that deepen participation and engagement. "The act of participating can be seen as bringing spaces to life as well as carving out new spaces and creating new social forms with their own momentum and impetus" (Cornwall, 2002, p. 2). This brings us to broader questions of social power and as Ercan and Dryzek (2015) argue, "democracy also needs to be deepened" by engaging participants in ways that are authentically deliberative and involving reflective participation $(2015, \mathrm{p}$. 243). Instead of just articulating viewpoints, a deliberative process also creates opportunities for these viewpoints to change (Curato et al., 2017). Thus, there is need to develop deliberative methods that increase participants' learning not only of issues, but of participation itself. Understanding participatory democracy includes how to argue, why to argue, when to argue, and with whom to argue.

\section{WHAT ARE DELIBERATIVE WALKS?}

Deliberative Walks synthesizes two established participatory methods - the discussion-centric Citizens Juries and the observation-oriented Development Walks (Raisio \& Ehrström, 2017). Deliberative Walks are: 
A participatory process in which the participants, by deliberating in small groups and joining facilitated walks, tackle a complex policy issue that has highly intertwined social and physical dimensions. (Raisio \& Ehrström, 2017, p. 29)

Before I discuss Deliberative Walks in more detail, I want to say more about the inspiration for the practice. The Citizens' Jury (CJ) method was invented in the early 1970s (Crosby \& Nethercutt, 2005). A typical Citizens Jury project lasts three to five days and the goal is to make sure that a group of people - randomly selected and demographically balanced - have enough time to learn about the issue from witnesses and to be able to deliberate among themselves about what they are learning (Crosby \& Hottinger, 2011). Information given to the jurors needs to be of high quality and facilitators guarantee the quality of deliberative discussions, guided by ideals of equality and fairness (Leighninger, 2014; Fung, 2015).

The origins of Development Walks (DW) in turn can be traced back to women's safety audits, developed in Canada in the late 1980s as a response to increasing concerns related to insecurity and violence against women (Lambrick \& Travers, 2008). Safety and security walks, developed in Sweden in the early 2000s, share many similarities with women's safety audits (Brå, 2009, p. 1). The focus of safety and security walks is on, both, the physical and social dimensions of localities; the underlying idea being that the ones who have the greatest knowledge of the local environments are those who actually live there (Raisio \& Ehrström, 2017). Ehrström and Katajamäki (2013) identified DW as an important method for citizen participation, with the learning process enhanced by in situ observations of specific situations and places and its capacity to concretize complex planning issues (Ehrström, 2015, p. 17).

Facilitated by the walk leader(s), participants proceed through a pre-defined route, record reflections and discuss their surroundings, after which participants develop proposals for development, summarize and communicate them to public officials (Raisio \& Ehrström, 2017). If a scribe is appointed, he/she will record the group experience. Written comments and pictures are of great help during the later deliberation phase, as non-documented reflections and impressions may too easily be forgotten, when deliberating in groups and drafting the resolution in plenum.

The potential of deliberative walks which builds on these two models of participatory processes was explored in two case studies implemented in Finland in 2014 by Raisio and Ehrström (2017). Both case studies have their shortcomings in relation to the ideal of Deliberative Walk; however, together they constitute a basis from which preliminary conclusions could be made. The Deliberative Walk approach makes it possible for participants to acquire a more direct and holistic experience of the issue they are deliberating on (Raisio \& Ehrström, 2017, p. 43) which also makes learning more equal. This combines theoretical elements and listening to experts and discussions which is complimented by in situ observations and recognition of a sense of place (by which I mean inhabitants' and citizens' understanding of 
the locality where they live and/or act), participation may be experienced as more equal by all participating groups. Well-educated, well-off, well-positioned citizens tend to dominate in situations based on theoretical learning and participation. The combination of different learning methods and a preparedness to value different skills and characteristics may give groups that are challenged by theoretical elements, a greater opportunity to contribute to a common learning experience. It is further argued that a combination of indoor and outdoor, place-based, learning, make deliberations more inclusive, and more interesting to participate in, especially for groups or individuals that prefer more practical forms of learning.

In this way Deliberative Walks provide a vehicle to learn in a more complete matter. This means to learn with all your senses, theoretically and by observing first-hand. The variation of learning methods and places as well as a possibility to contribute in other ways - by using all senses (feeling, smelling, seeing, hearing, touching) and having practical knowledge and sense of place - may enhance political participation and "re-engag[e] a disillusioned and disenchanted citizenry" (Smith, 2009, p. 4).

Deliberative Walks, then, is a more complex deliberative method than either CJ or DW and the use of these various methods as a pedagogical and methodological set of practices as explored below in relation to two case studies. The first case study Pirkka14 was initially designed as a Citizens Jury and kept this title but used the DW model as described above. Pirkka14 gave us an opportunity to also test a situationbased observation, and thus a (somewhat impure) Deliberative Walks experiment. The second case study Campus Forum, was planned and carried out in accordance with the Deliberative Walks method. Early results are also presented from a pilot study 'Studentlab Deliberative Walks'. The results of the case studies were jointly analyzed, and research was conducted through an analysis of semi-structured interviews with participants. The Pirkka14 Citizens Jury took place in October 2014 in Finland. Raisio was in charge of this case (a situation-based Deliberative Walks experiment), while I was in charge of the second case study (Campus Forum, a place-based Deliberative Walks experiment).

\section{Pilot Case I: Pirkka14 Citizen's Jury}

Pirkka14 (an emergency preparedness exercise by civil authorities) and Wanaja14 (Finnish armed forces defense training) were implemented simultaneously for the joint training of civil authorities and armed forces. As noted above Pirkka14, was somewhat confusingly, called a Citizens Jury (partly due to it being already planned and named so by the participating/organizing authorities). The CJ consisted of three days of deliberation (five hours per day) and a press event. The first day began with an introduction, and a video described the scenario. Then the jurors were divided to two small groups, both with a facilitator and a scribe. After these initial deliberations jurors had a chance to ask questions from the expert panel. On the second day the deliberations continued in small groups and the day ended with the observation of an accident simulation in the field. The simulation - an explosive laden military truck 
catching fire - tested the new local defense concept and the co-operation between civil authorities and armed forces. Jurors observed while a commentator narrated the sequence of events, and they could ask questions. On the third day the focus was on writing the declaration. On the fourth day jurors presented the declaration in a media event, after which official statements were requested from various stakeholders (Raisio \& Ehrström, 2017).

The unique off-site component, however, makes it an interesting case study from the point of view of Deliberative Walks (Raisio \& Ehrström, 2017). During the research, jurors reflected on different ways of learning. Interestingly, these did not include only learning by hearing and seeing, but also by feeling. For example one of the jurors described this multitude of learning opportunities: "It is always that when we, after the theoretical part, leave to the 'field', people can then use their ears and eyes and heart and to see" (J2) (Raisio \& Ehrström, 2017).

The role of feeling and experiencing was also noted in relation to the accident simulation. Being in the dark with the flashing lights of emergency vehicles, not knowing what will come next, was considered thrilling by some; such conditions clearly differing from those of a "nice warm classroom" (J2).

Participants thought the accident-simulation in combination with more theoretical learning was a novel approach that also made it possible to simulate reactions with other senses, like seeing, hearing and smelling. This combination of theoretical learning and practical experiences influenced new ways of thinking and deliberating about the subject.

\section{Pilot Case II: Campus Forum}

Campus Forum pilot study was organized strictly in accordance with the Deliberative Walks method. It took place in November 2014, as part of the national New Locality project (2011-2015), administered by The Finnish Federation of Settlement Houses. Previously it had been contemplated how synergies between different institutions could be increased and how the campuses in the locality could be more open to local inhabitants. It was thought that a more participatory practice, such as a Deliberative Walk, could give novel insights to the issue leading to the Campus Forum being tasked with a question of "how to create a common campus for all" (Raisio \& Ehrström, 2017).

I was in charge of the Campus Forum Deliberative Walks, as well as leading the Development Walk element, and as facilitator in one of the discussion groups. Research was conducted by analyzing semi-structured interviews with participants after completing the Campus Forum.

Campus Forum was organized in 3.5 hours long sessions over three evenings. The first began with a presentation of the process and the theme, and getting to know each other, followed by three expert presentations. Participants had the opportunity to ask questions, after which they were divided into two subgroups for discussions, 
with a facilitator and a scribe appointed for each group. The day ended with a short common discussion.

The second day was "Development Walk Day" on campus. The walk leader held a short introduction and then guided the group on a two hour route, via eight stops, where different experts/managers held short informative presentations. The participants then had the opportunity to ask questions. A minute-maker made notes and took photographs. The participants then gathered indoors for discussion and reflections, with some presenters joined in, an unplanned added value.

The third day followed a Citizens' Jury pattern, with participants deliberating and writing a declaration. A week later, at a presentation seminar, the declaration including five proposals - was handed over, and the process of the Campus Forum was presented. Representatives of the city and institutes of higher education were given the floor for comments. Discussion followed. Media attended the seminar, resulting in articles in local newspapers.

Contrary to traditional CJs, in which the objective is to form a local population in miniature, with the Campus Forum the aim was to gather a heterogeneous sample of different stakeholders, e.g. inhabitants of the locality, local entrepreneurs, students and employees of the institutes of higher education. Eighteen persons registered, seventeen participated. Six students, four employees on campus, three entrepreneurs, and four inhabitants, across a wide age range. However, of the seventeen participants only six participated for the whole duration of the Campus Forum. Partly this is due to miscommunication from gatekeepers, as four one-day participants announced that they had thought Campus Forum was a one-night event. This, of course, had implications for the process, as the number of participants during the whole Deliberative Walk became very low. In hindsight, the researchers themselves should have provided the information to all relevant groups.

Following the ideals of outdoor and place-responsive pedagogics (Wattchow \& Brown, 2011) participants described how they had embodied encounters with different places as well as hearing many place-based narratives from the experts/ managers. The expert presentations of the first day and the walk on the second day were considered to support each other, and the walk made issues tangible: as one male participant explained "[the walk] is where it really starts. Although there were discussions, through the walk one saw how things really were". An inhabitant participating said "It was so great ... I would say the best (part). It suited it perfectly. It sure was much better than watching a video or something, it was so much better to see the entire place". One participant highlighted the use of different senses:

These are several senses then, and you can see visually in front of you what people are talking about, instead of just talking about it or see the image ... you're there and you see it in three dimensions, yes. (Raisio \& Ehrström, 2017)

Those who were not very familiar with the campus welcomed the walk-about session and the input of experts/managers in particular, as their presentations supplemented 
each participant's own observations of the surroundings. Walking encouraged and stimulated discussions.

Participants strongly pointed out the value of combining different forms of learning and appreciated place-based learning and in situ-observations as an ingredient of the deliberative learning process. Based on these two case studies, Raisio and Ehrström (2017) suggest that:

in place-specific deliberations, a Deliberative Walk is a suitable method when the issue that is being tackled has highly intertwined social and physical dimensions, while in more situation-specific deliberations, a Deliberative Walk adds value when the issue is such that needs a more complete and direct learning experience ... Sometimes a single CJ or a single Development walk is not enough; a combination is called for. (Raisio \& Ehrström, 2017, pp. 28, 44)

The case studies were not without limitations. Neither study fully met the ideal of Deliberative Walk. The off-site component of Pirkka14 Citizens' Jury was observation-oriented and the activity on the field was limited. Campus Forum had a more active field experience, but suffered from a limited number of participants. Overall, participants valued combining theoretical input (discussions, expert lectures, Q\&A sessions) and place-based physical observations as it strengthened the learning process and increased their understanding of this participatory method as well as the issue and place/situation under deliberation.

\section{STUDENTLAB DELIBERATIVE WALKS}

Learning to deliberate is core to our development as democratic citizens (Carney \& Harris, 2012). This approach was also crucial to the Studentlab Deliberative Walks, where Lindell and I piloted a new place-based method for citizen participation and different learning methods, to increase student activity and interest in participatory democracy and deliberations in society. It was a cooperation between Adult Education (Ehrström) and Political Science (Lindell), and formally a pilot master course in Adult Education.

The idea was to create an interdisciplinary mini-public of students from different backgrounds, both domestic and international students from different disciplines. 21 students enrolled, 19 participated in the whole course, 9 domestic and 10 international students. 18 students completed all assignments (for 5 ECTS).

We designed a Deliberative Walk experience on the redevelopment of Åbo Akademi University campus and neighboring sites - silo buildings, nearby seashore, and Kuntsi Museum of Modern Art. Choosing a current municipal topic, the arrangers also hoped that the Studentlab resolution could influence the municipal planning debate, and therefore, as a potential added-value, give students a taste of "real life"-politics. Studentlab was organized in October 2017, consisting of five half-day elements (4 hours each) (see Table 17.1). 
Table 17.1. The "Studentlab: Deliberative Walks" process

\begin{tabular}{|c|c|c|}
\hline \multicolumn{3}{|c|}{ How should the university campus and surrounding areas be redeveloped? } \\
\hline Day 1: & Introduction/Theory Day & $\begin{array}{l}\text { Information about the process, deliberative and } \\
\text { participatory democracy, place-based learning and } \\
\text { the Deliberative Walks method, pre-questionnaire. }\end{array}$ \\
\hline Day 2: & Citizens' Jury Day & $\begin{array}{l}\text { Three Q\&A sessions with four experts (about } \\
\text { deliberative theories, architecture, arts and } \\
\text { environments), followed by small-group } \\
\text { discussions and a plenum discussion. }\end{array}$ \\
\hline Day 3: & Development Walk Day & $\begin{array}{l}\text { Development Walk on campus and surrounding } \\
\text { areas, including six stops with expert } \\
\text { introductions (representing Åbo Akademi } \\
\text { University, Student Union, Museum of Modern } \\
\text { Art, city planning department, and citizen } \\
\text { association). Local media attended. Followed by } \\
\text { plenum discussions. }\end{array}$ \\
\hline Day 4: & Deliberation Day & $\begin{array}{l}\text { Citizens Jury small group and plenum } \\
\text { discussions, writing of joint declaration with five } \\
\text { (re)development proposals for Campus area and } \\
\text { surroundings. }\end{array}$ \\
\hline Day 5: & $\begin{array}{l}\text { Presentation Seminar } \\
\text { Day }\end{array}$ & $\begin{array}{l}\text { Declaration with proposals presented and handed } \\
\text { over to relevant decision-makers from City of } \\
\text { Vaasa and Åbo Akademi University Dean of FPV, } \\
\text { with local media present, post-questionnaire. }\end{array}$ \\
\hline
\end{tabular}

Results based on questionnaires and essays indicate that student knowledge and interest in participatory democracy and deliberative methods increased during this course. Interest to participate in education that combines theoretical and place-based elements also increased.

Most students had low or non-existent prior knowledge of deliberative methods, prior experiences of participatory democracy in education were more varied, but only a small fraction had extensive experience of this. Participants either had significant prior experience of combining theoretical and place-based learning ( 9 scored 4 or 5 , on a scale $1-5$ ) or little or none (16 scored $0-2)$. Thus, the individual starting-points were very different.

Questionnaires clearly show that both knowledge and interest to participate improved overall. Interestingly, student interest to participate in participatory democracy and deliberations in society clearly increased. 10/19 mark a strongly increased interest (scoring 4 to 5 on a scale $0-5$ ), with as many as seven (more than a third) scoring a full five. The remaining nine participants scored 3 . This suggests that the interest to participate in society increased, at least somewhat, for all participants. Thus, Studentlab succeeded in educating (potentially) more active citizens. 
The participants' knowledge of deliberative methods increased significantly. More than half the group (11/19) scored 4 or 5 (on a scale $0-5$ ), none scored under 3 . Increased knowledge of participatory democracy was also clearly stated, as 11/19 answered 4 or 5 (on a scale $0-5$ ), and, again, none less than three.

$11 / 19$ participants also scored a full 5 on the question "Has this course increased interest in combining theoretical and place-based learning?" A further five scored 4 and three scored 3 (on a scale $0-5$ ). Interest in place-based learning received a slightly more varied answer, but still positive. Eight scored a full 5, four scored 4, six scored 3, and only one scored a 2. Strong support for the Development Walk element was evident with $15 / 19$ participants singling out the walk (wholly or partly) as the most important element in their learning process.

Participants described their willingness to participate more actively in society, to use newly gained knowledge of deliberative methods by, for example, conducting deliberative walks or development walks, with children (suggested by an international student of pre-school pedagogy), while another international student proposed a similar Studentlab course at her own University campus.

At the presentation seminar, a representative of the City planning authority quite bluntly dismissed the students' proposal, when handed the declaration. The representative concluded that the silos will be demolished (even though a formal, democratic, decision by the city council was yet to be made). This angered and disappointed many students, but it could perhaps also be seen as a valuable lesson in real-life politics.

Hence, the presentation seminar, rather unplanned, gave students a glimpse of power structures and decision-making in society and outside elected political bodies. The importance of "getting the word out" and experiencing the role of media means that the question of media strategy may also be taken into consideration in future Studentlabs. Here roughly half the group, 9/19 participants, were interviewed by media. For most students, this was a first experience, and students not interviewed still experienced media presence and media coverage.

Students clearly enjoyed the combination of theoretical and place-based in situobservations. Their interest increased for combinations of these forms of learning. Even though the sample is small (18 students completed all course tasks to be awarded 5 ECTS points) it is suggested that a combination and variation of methods were experienced positively and increased learning.

\section{CONCLUSIONS AND DISCUSSION}

In both case studies (Raisio \& Ehrström, 2017) and in the Studentlab experience, the combination of theoretical and place-based learning methods strengthened the learning process. Participants in all cases singled out the structured walk as the most important element for their learning process.

The presentation seminar also highlighted important challenges for Deliberative Walks to be truly successful. Political planning processes, for example, are time- 
consuming and may finish long after the DW experience has ended, policy-makers may be dismissive of DW declarations or may be organized for general awarenessraising rather than direct policy impact. In these cases, strategies are required for how the DW proposals can be seriously considered by decision-makers and clearly communicated.

Respect, tolerance, patience, empathy, and being open-minded are some of the values that we learned during the group discussions", noted one international student of the Studentlab, while another emphasized: "The deliberative walks and democracy part grew my political efficacy, and the interaction with the city officials diminished my political efficacy. (Lindell \& Ehrström, 2018)

It is important to reflect upon the impact of sequencing in Deliberative Walks. Would the outcome change if the elements were realized in a different order? Goodin and Niemeyer (2003) argue that reflection and focusing attention on an issue will generate "internal-reflective deliberation" and state that this is likely to happen in earlier stages of deliberation and will have a large impact on participants. Lindell and Ehrström (2018) in turn note that the development walk sequence (in Studentlab Deliberative Walks) had a more profound impact on participants, which was sequenced in the opposite order, with theoretical content first, followed by in situ-observations.

The Deliberative Walk method takes sequencing into account as it may indeed influence the learning process. I argue that it increases the value of observation to first have learned about the issue at hand, as well as the deliberative method and process. It afforded opportunities to theoretically problematize issues under discussion. Without understanding the issue at hand and method, important observations may go unnoticed or processed in an unreflective way. Listening to experts, asking questions and discussing together means that participants from different backgrounds share information and initial perspectives before making common in situ-observations. All participants will then be instructed to observe with all senses (smell, see, hear, touch, feel, "sense"), which makes the walk experience in itself more equal, irrespective of prior experiences and knowledges.

Deliberative Walks, then, include elements visualized in a Deliberative Walks Learning Process Wheel. I call the elements in the process Problematize (theoretical input, Citizens Jury), Observe (In-situ observations, Development Walk), Reflect (Deliberation, discussions, compromises, writing of common declaration), Act (Presentation of declaration and propositions to decision-makers, public and (in) media). A fifth element, Summarize (reflections on the result and process as a whole, and the outcome of the DW), complete the Learning Process Wheel. This concluding summarization may then be a spark for a new or continuing process, starting with new theoretical input and problematization.

From a democratic point of view, it is vital to note that participation and deliberation based on interacting with experts in "classrooms" and reading texts, tend to strengthen the position of the already powerful, that is, the well-educated, 


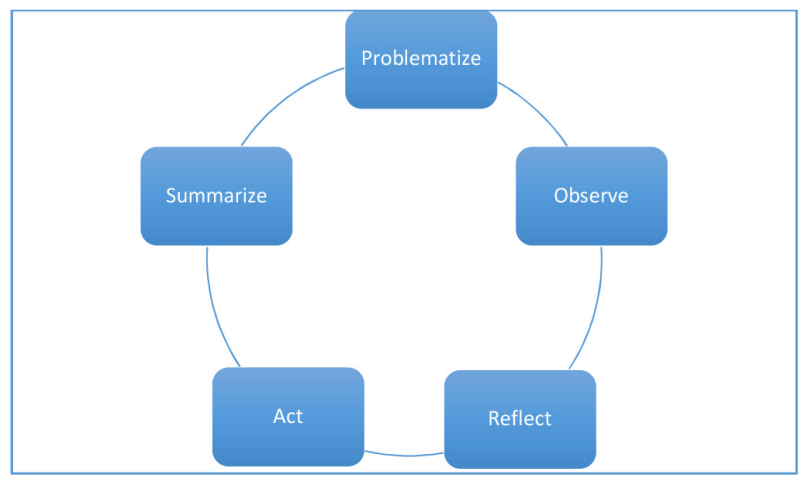

Figure 17.1. The Deliberative Walks learning process wheel

well-off and well-positioned citizens. For other groups, this challenges their rights and possibilities to participate in an equal way. Facilitators are instructed to distribute speaking turns equally and emphasize different ways of learning, but they cannot change the fact that participants differ in background and experience of theoretical learning situations.

Combining theoretical classroom-based learning with place-based learning, insitu observations, diverse skills and knowledge within a group and holistic embodied learning has enormous potential for learning and research. Different groups and individuals bring different qualities, skills and experiences to the deliberations, and thus widen the group's knowledge base. Sharing thoughts, seeking compromises and discussing (under the guidance of facilitators) may then result in novel insights and learning.

Deliberative Walks include a strong element of variation, and this, I argue, improves the learning process. The experience is not the same, but very different, every time the participants meet. Interviews with participants especially highlight the Development Walk element, that is, in situ-observations, as the most important element in enhancing learning. The physical walk element may be the most important, and obviously the most appreciated, part of a Deliberative Walk experience, but I argue that it actually is the variation and combination of methods that is the most important feature of Deliberative Walks. I further argue that this method is well suited for civic participation and planning processes. In contested and/or transforming places it may be a tool for improving social sustainability, where a Deliberative Walk bring different stakeholders and interest groups to the same table and walk, in order to find common ground to agree upon. Deliberative Walks implies to plan with people, instead of planning for people, or over the heads of people. 


\section{REFERENCES}

Brå. (2009) Safety and security walks: The Swedish National Council for crime prevention. Retrieved from http://www.veilig-ontwerp-beheer.nl/publicaties/safety-and-security-walks

Carney, G. M., \& Harris, C. (2012, May). Citizens'voices: Experiments in democratic renewal and reform. Irish Centre for Social Gerontology, IRCHSS.

Cornwall, A. (2002). Locating citizen participation. IDS Bulletin, 33(2), 49-58.

Crosby, N., \& Hottinger, C. J. (2011). The citizens jury process. In Book of the states 2011 (pp. 321-325).

Crosby, N., \& Nethercut, D. (2005). Citizens juries: Creating a trustworthy voice of the people. In J. Gastil \& P. Levine (Eds.), Deliberative democracy handbook: Strategies for effective civic engagement in the twenty-first century (pp. 111-119). San Fransisco, CA: Jossey-Bass.

Curato, N., Dryzek, J., Ercan, S. A., Hendriks, C. M., \& Niemeyer, S. (2017). Twelve key findings in deliberative democracy research. Daedalus, Symposium on Deliberative Democracy, 146(3), 28-38.

Ehrström, P. (2015). Uusi paikallisuus-hanke ja keskusteleva demokratia [The new locality project and deliberative democracy] (Raportti 11/2015). Helsinki: Settlementtiliitto. Retrieved March 19, 2018, from http://setlementti-fi-bin.directo.fi/@Bin/fdd3a5da49350416260dd4b114618ef1/1468417955/ application/pdf/1024628/Peter_Ehrstr\%C3\%B6m_Uusi\%20paikallisuus\%20-hanke\%20ja\%20 keskusteleva\%20demokratia.pdf

Ehrström, P., \& Katajamäki, H. (2013). 'Paikallisuuden ytimessä: Tarkastelussa Vaasan Palosaari' [In the core of locality: A study of Palosaari, Vaasa]. In I. Luoto, H. Katajamäki, \& N. Lundström (Eds.), Oppiva alue, menestyvä alue - Juhlakirja professori Seija Virkkalan 60-vuotispäiväksi (Vol. 275, pp. 61-80, Acta Wasaensia series). Series 12. Vaasa: Vaasan yliopisto.

Ehrström, P., \& Raisio, H. (2014). Deliberative walks - A new participatory method for urban from planning (Abstract). Deliberatiivisen Demokratian Instituutti R\&D Day. Retrieved March 19, 2018, from http://www.deliberaatio.org/ delibero/wordpress/?p=758

Ercan, S. A., \& Dryzek, J. S. (2015). The reach of deliberative democracy. Policy Studies, 36(3), 241-248. doi:10.1080/01442872.2015.1065969

Fung, A. (2015). Putting the public back into governance: The challenge of citizen participation and its future. Public Administration Review, 75(4), 513-522.

Goodin, R. E., \& Niemeyer, S. J. (2003). When does deliberation begin? Internal reflection versus public discussion in deliberative democracy. Political Studies, 51, 627-649.

Lambrick, M., \& Travers, K. (2008). Women's safety audits: What works and where? (Safer Cities Programme, UN-Habitat).

Leighninger, M. (2014). What we're talking about when we talk about the "civic field" (and why we should clarify what we mean). Journal of Public Deliberation, 10(1), 8. Retrieved from https://www.publicdeliberation.net/jpd/vol10/iss1/art8

Lindell, M. (2015). Deliberation och åsiktsförändring: En studie av individegenskaper och gruppkontext [Deliberation and opinion change: A study of individual characteristics and group context]. Turku: Åbo Akademi University Press.

Lindell, M., \& Ehrström, P. (2018, September 5-7). Deliberative walks - Civic participation in locallevel planning processes. Full paper presented at the Participatory Spaces in Perspective, International Conference of the Participatory and Deliberative Democracy Specialist Group of the Political Studies Association, University of Westminster, London (In panel "Shaping Participatory Spaces I: Facilitating Participation).

Prosser, B., Flinders, M., Jennings, W., Renwick, A., Spada, P., Stoker, G., \& Ghose, K. (2018). Pedagogy and deliberative democracy: Insights from recent experiments in the United Kingdom. Contemporary Politics, 24(2), 210-232. Abingdon: Routledge, Taylor \& Francis Group.

Raisio, H., \& Ehrström, P. (2017). Taking deliberation to the streets: Reflections on deliberative walks. Scandinavian Journal of Public Administration, 21(4), 27-51. Retrieved from http://ojs.ub.gu.se/ojs/ index.php/sjpa/article/view/3517/3383

Smith, G. (2009). Democratic innovations: Designing institutions for citizen participation, Cambridge: Cambridge University Press. 


\section{P. EHRSTRÖM}

Szczepanski, A. (2013). Platsens betydelse för lärande och undervisning - Ett utomhuspedagogiskt perspektiv [The importance of place for learning and teaching - An outdoor educational perspective]. NorDiNa, 9(1), 3-17.

Wattchow, B., \& Brown, M. (2011). A pedagogy of place: Outdoor education for a changing world. Melbourne: Monash University Publishing. 